\author{
가습기 살균제 제품에 표기된 안전보건정보 고찰 \\ 박동욱*†·이승희*·임흥규*·배서연*·류승훈**·안종주*** \\ *한국방송통신대학교 환경보건학과 \\ **서울대학교 보건대학원 환경보건학과 \\ ***한국사회정책연구원
}

\title{
Review on Safety and Health Information on Humidifier Disinfectant
}

\author{
Dong-Uk Park*†, Seunghee Lee*, Heung-Kyu Lim*, Seo-Youn Bae*, \\ Seung-Hun Ryu**, and Jong-Ju Ahn*** \\ *Department of Environmental Health, Korea National Open University \\ **Department of Environmental Health Sciences, Graduate School of Public Health, Seoul National University \\ ***Korean Social Policy Institute
}

\begin{abstract}
The objective of this study is to review the safety and health information displayed on containers of humidifier disinfectants (HD). We summarized not only general characteristics related to the marketing and manufacturing of HD, such as the duration sold and the name of the company, but also the safety and health information, such as identification of disinfectants, recommended use volume, and precautions. All of this information was reviewed by HD brand. We collected safety and health information from $31 \mathrm{HD}$ brands. We found that companies that sold and manufactured HD brands differ. Two companies were found to sell their HD without permission after 2011 when the health effects caused by HD were widely known. The name of the disinfectants were not identified on the container of HD. The recommended volumes were found not to be based on toxicological evidence and set without consideration of the level of susceptibility of users. Most companies displayed phrases such "this HD is safe for humans, even children" on the front of the container. No inhalation and skin toxicity precautions were provided. In conclusion, most HD did not properly display information related to safety and health to protect the health of HD users. There has been no official investigation to evaluate the risks posed by HD, such as the sales volume by HD, identification of chemical disinfectants, or their concentration, nor have there been actions to control the chemical quality of HD. In addition, government actions to punish the malicious practices of companies that manufactured and sold HD were found to inappropriate
\end{abstract}

Keywords: Household chemical, humidifier disinfectant brand (HD), inhalation toxicity, safety and health information

\section{I. 서 론}

가습기 살균제 사용으로 피해를 입었다고 신고한 사람은 2017년 10월 23일 기준으로 5,790명이었고,
이 중 사망자는 1,256 명 $(21.7 \%)$ 이었다. 피해 신고자 중 임상검사와 환경노출 조사를 마친 1,199명(1차조 사: 361명, 2차조사: 169명, 3차조사: 669명)에서 가 습기 살균제와 연관이 있다고 판정된 폐 손상자는

${ }^{\dagger}$ Corresponding author: Department of Environmental Health, Korea National Open University, Seoul, 03087, Korea, Tel: +82-2-3668-4707, Fax: +82-2-741-4701, E-mail: pdw545@gmail.com Received: 15 October 2017, Revised: 23 October 2017, Accepted: 24 October 2017 
303 명으로 $25 \%$ 나 된다. ${ }^{1,2)}$

가습기 살균제 건강피해가 참사수준임에도 불구 하고 1994년부터 유통된 가습기 살균제 제품(이하 제품) 수, 제품별 연도별 판매량, 제품 내에 들어있 는 살균제 성분과 농도 등에 대한 기본적인 내용 도 조사되지 않고 있다. 2014년에 보건복지부 질병 관리본부 폐손상조사위원회에서 1 차 폐 손상 판정 결과까지 정리하여 발간한 “가습기 살균제 건강피 해 사건 백서"가 유일한 국가보고서이다."3) 이 보고 서에는 가습기 살균제의 전체 제품 수, 판매량, 제 품에 함유된 화학물질 등에 대한 일부 구체적인 정 보가 있기는 하지만 충분하지 못하다. 2014년 이후 진행되어온 가습기 살균제 피해현황 등을 종합한 국가보고서는 아직 나오지 않고 있다. 본 연구에서 는 가습기 살균제 제품 용기에 표기된 제품의 일 반적 특성과 건강위험을 나타내는 안전보건정보를 정리하고, 이들 정보에 대한 신뢰성과 쟁점들을 고 찰했다. 또한 기업의 가습기 살균제 제품 위험관리 에 대한 환경부, 공정거래위원회 대응 현황도 고찰 했다.

\section{II. 연구 방법}

제품은 폐 손상 피해 신고자, 환경보건시민센터, 환경부로부터 연구 목적으로 기증받았다. 총 37 개 제품의 용기에 표기된 안전보건정보를 확인하였으 나, 6개 제품(파란하늘 맑은 가습기, SK 가습기메 이트, 바이오피톤 가습기 무균, 에코후레쉬 가습기 항균볼, 닥터 $\mathrm{OK}$ 안전가습, 동산 가습기메이트)은 용 기 또는 사진이 없거나 훼손되어 안전보건정보를 파 악할 수 없었다. 이에 최종 31 개 제품의 용기에 표 기된 일반적 특성과 안전보건정보를 아래와 같이 구 분해서 정리하였다.

- 제품별 일반정보인 판매기업, 제조기업, 제품 용 량, 판매 시기는 환경부 자료와 인터넷 자료 등 을 참조했다.

- 제품별 살균제 성분 정보 표기 및 제품별 살균 제 성분은 그 동안 보고된 문헌과 비교했다.

- 제품별 안전보건정보는 제품용기 앞면과 뒷면에 표기된 핵심 내용을 요약했다.

- 제품별 사용방법은 권장량을 포함한 사용상의 주 의사항 등으로 요약했다.
- 제품의 위험관리, 제품별 폐 손상 등 건강피해에 대한 환경부, 공정거래위원회의 대응 및 검찰조 사 내용을 확인했다.

\section{III. 연구 결과}

\section{1. 제품별 일반 정보 현황}

제품별 판매기업, 제조기업, 용량, 판매시기 등 일 반적 특성을 정리하였다(Table 1). 제품의 생산기업 과 판매기업 대부분이 다른 것을 확인할 수 있었 다. "맑은 나라" 제품은 판매시작 시기(2006년)만 있었다. 2개 제품(이코볼 살균필터, 세균닥터(정제형)) 은 2016년까지 판매된 것으로 조사되었다. 대부분의 제품 판매가 금지되었던 2011년 말 이후 이코볼 살 균필터와 세균닥터(정제형) 제품은 의·약외품 허가를 받지 않고 판매되었다.,5)

\section{2. 제품별 안전보건 위험 정보 현황 \\ 1) 살균제 성분}

31 개 제품 중 6 개 제품(세퓨 가습기살균제, 엔위드 (파란색), 아토오가닉, 아토세이프 가습기 청정제, 아 토세이프 가습기 항균제, 세균닥터(정제형))만이 살균 제로 사용한 화학물질 성분을 표기했다. 그 외 모든 제품은 화학물질의 살균제 성분이 아닌 '살균제', '미 생물 성장 억제 성분' 등과 같이 용도로 표기했다. 용 도 정보는 건강 위험 정보로서의 경고 의미가 없다. 대부분의 제품에는 건강 위험물질인 살균제가 들어 있었지만 그 성분을 표기하지 않았다. 폐 손상 등 가 장 많은 가습기 살균제 건강 피해를 초래했던 “옥시 싹싹 뉴 가습기 당번” 등도 성분을 표기하지 않았다.

\section{2) 살균제 사용 권장량 등 사용방법}

29 개 제품은 사용방법(권장량)을 표기했으나 2개 제품(하이지어(필터용, 딤채형), 에어가드 리퀴드)은 표기하지 않았다. 제품 대부분의 사용 권장량은 $2 \sim 3 \mathrm{~L}$ 희석할 물 용량을 기준으로 약 $10 \mathrm{~mL}$ 로 표기했다 (Table 2). '가습기 클린업'은 같은 제품임에도 불구 하고 판매시기별로 살균제 성분(편백나무 추출액: 2005-2010, polyhexamethylene guanidine hydrochloride (PHMG 염산염, CAS No. 57028-96-3): 2010-2011) 의 권장 사용량이 달라진 것을 확인할 수 있었다. 사용 권장량에 대한 독성학적 근거나 정보는 파악할 
Table 1. General characteristics by humidifier disinfectant brand

\begin{tabular}{|c|c|c|c|c|c|}
\hline No. & 제품이름 & 판매기업 & 제조기업 & 용량 $(\mathrm{mL})$ & 판매시기 \\
\hline 1 & 유공 가습기메이트 & 유공/선경그룹 & \multicolumn{2}{|c|}{ 유공 바이오텍 사업부 230} & 1994-1996 \\
\hline 2 & 가습기당번 & 옥시 & $\mathrm{NI}^{*}$ & 300,550 & $1996-2000$ \\
\hline 3 & 119 가습기살균제 & $\begin{array}{l}\text { 엘지화학/(주)엘지생활 } \\
\text { 건강 }\end{array}$ & 양양산업주식회사 & 250 & $1997-2003$ \\
\hline 4 & 옥시싹싹 뉴 가습기 당번 & 옥시 레킷벤키저 & 한빛화학 & 300,550 & $2000-2011$ \\
\hline 5 & 옥시싹싹 가습기당번(고체형) & 옥시/옥시 레킷벤키저 & 처한빛화학/화인케미칼 & $8 \mathrm{~g}$ & $2000-2011$ \\
\hline 6 & 애경 가습기메이트 & 애경산업 & SK 케미칼 & 1000 & $2002-2011$ \\
\hline 7 & 주부사랑 가습기파트너 & 롯데쇼핑 & (주)샤인업 & 1000 & 2003-2004 \\
\hline 8 & 홈플러스 가습기청정제 & 삼성테스코 & 용마산업사 & 550 & $2004-2011$ \\
\hline 9 & 앤 위드(파란색) & 뉴트리아 & 메덴텍 & 30정, 50정 & 2005-2009 \\
\hline 10 & 이플러스 가습기살균제 & 신세계이마트 & $\begin{array}{l}\text { 애경산업/SK케미칼/ } \\
\text { 필러물산 }\end{array}$ & 500 & $2006-2007$ \\
\hline 11 & 와이즐렉 가습기살균제 & 롯데쇼핑 & 용마산업사 & 1000 & $2006-2011$ \\
\hline 12 & 맑은나라 & 맑은나라 & $\mathrm{NI}$ & 800 & 2006-NI \\
\hline 13 & 홈워쉬 & 신희 & 신희 & 1000 & $2007-2008$ \\
\hline 14 & 홈키파 가습기 한번에 싹 & 헨켈홈케어 코리아 & 에버코스 & 1070 & $2007-2009$ \\
\hline 15 & 가습기 클린업 & 홈케어 & 글로엔엠 & 1000 & $2005-2011$ \\
\hline 16 & 가습기퍼니셔 & 다이소아성산업 & 산도깨비 & 1000 & $2007-2010$ \\
\hline 17 & 이마트 가습기살균제 & 신세계이마트 & 애경산업 & 500,1000 & $2007-2011$ \\
\hline 18 & 함박웃음 가습기세정제 & GS리테일 & 퓨앤코 & 500,1000 & $2007-2011$ \\
\hline 19 & $\begin{array}{l}\text { 이코볼 살균필터(MF-200) } \\
\text { /에코볼 필터(MTF-300) }\end{array}$ & 엠텍/엠테크윈 & 동보기전/엠테크윈 & 2 개 & $\begin{array}{l}2007-2016 / \\
2013-2016\end{array}$ \\
\hline 20 & 하이지어(필터용, 담채형) & 이너웍스 & 불스원신소재 & $60 \mathrm{~g}$ & $2008-2010$ \\
\hline 21 & 세퓨 가습기살균제 & ButterflyEffect & 크린코퍼레이션 & 500,10 (파우치형 & )2009-2011 \\
\hline 22 & 아토오가닉 & 아토오가닉 & ButterflyEffect & 300 & 2009-2011 \\
\hline 23 & 항알레르겐 & 베이비덕월드 & 크레인(미국) & 236 & 2009-2011 \\
\hline 24 & 아토세이프 가습기 청정제 & SM Korea & SM Korea & $150,500,1000$ & 2009-2011 \\
\hline 25 & 아토세이프 가습기 항균제 & 아토세이프 & $\mathrm{NI}$ & 150 & $2009-2011$ \\
\hline 26 & 앤위드(흰색) & 클라나드 & 메 덴텍 & 30정, 50정 & $2010-2011$ \\
\hline 27 & 모던라이프 가습기 살균볼 & 뉴트리케어 & 워터엔피플 & $20 \mathrm{~g}$ & 2010-2011 \\
\hline 28 & 세균닥터(정 제형) & 신성 $\mathrm{GB} \& \mathrm{C}$ & 메덴텍 & 70정 & 2013-2016 \\
\hline 29 & 에어가드 리퀴드 & 웰버스 & NI & 500,1000 & NI \\
\hline 30 & 한국까르푸가습기세정제 & 한국까르프 & 애디켐/코비스산업 & 500,1000 & NI \\
\hline 31 & 한방가습기보충액 & 써브라임 & NI & 250 & NI \\
\hline 32 & 동산 가습기메이트 ${ }^{\dagger}$ & $\begin{array}{l}\text { 동산 } \mathrm{C \& G} / \mathrm{SKM} \\
\text { (선경마그네틱스) }\end{array}$ & NI & 230 & $1994-2000$ \\
\hline 33 & 파란하늘 맑은 가습기 ${ }^{\dagger}$ & 애경산업 & NI & 280 & 1997-1999 \\
\hline 34 & $\mathrm{SK}$ 가습기메이트 ${ }^{\dagger}$ & SK케미칼 & 연희산업 & NI & 2001-2004 \\
\hline 35 & 에코후레쉬 가습기용 항균볼 ${ }^{\dagger}$ & $\mathrm{JnK}$ 사이언스 & & $6 \mathrm{~g}$ & 2009-2011 \\
\hline 36 & 바이오피톤 가습기 무균 ${ }^{\dagger}$ & 바이오피톤 & NI & 400 & NI \\
\hline 37 & 닥터OK 안전가습 ${ }^{\dagger}$ & 연희산업 & NI & $\mathrm{NI}$ & NI \\
\hline
\end{tabular}

"NI, no information; "자료부족으로 제외 품목. 
Table 2. Basic safety information about chemical disinfectants added into humidifier by humidifier disinfectant brand

\begin{tabular}{|c|c|c|c|c|}
\hline No. & 제품이름 & 사용권장량 & 성분표기 & 확인된 성분 \\
\hline 1 & 유공 가습기메이트 & 1 회 약 $10 \mathrm{ml}(2 \sim 3 \mathrm{~L}$ 기준 $)$ & 미생물 번식억제성분(1.0\%) & $\mathrm{CMIT}^{*} / \mathrm{MIT}^{\dagger}$ \\
\hline 2 & 가습기당번 & 1 회 약 $10 \mathrm{ml}(2 \sim 3 \mathrm{~L}$ 기준 $)$ & 살균제 & PHMG P* \\
\hline 3 & 119 가습기살균제 & 물 $1 \mathrm{~L}$ 당 $5 \mathrm{ml}$ & $\mathrm{NI}^{\S}$ & NI \\
\hline 4 & 옥시싹싹 뉴 가습기 당번 & 1 회 약 $10 \mathrm{ml}(2 \sim 3 \mathrm{~L}$ 기준 $)$ & 살균제 & PHMG P \\
\hline 5 & $\begin{array}{l}\text { 옥시싹싹 가습기당번 } \\
\text { (고체형) }\end{array}$ & $8 \mathrm{~g} / 6$ 개월 & $\begin{array}{l}\text { 은 함유 무기계 용출형 } \\
\text { 유리성분 }\end{array}$ & NI \\
\hline 6 & 애경 가습기메이트 & 약 $10 \mathrm{ml}(2 \sim 3 \mathrm{~L}$ 기준 $)$ & 미생물 성장 억제 성분 & CMIT/MIT \\
\hline 7 & 주부사랑 가습기파트너 & 1 회 $10 \mathrm{ml}(2 \sim 3 \mathrm{~L}$ 기준 $)$ & 미생물 성장 억제 성분 & CMITMIT \\
\hline 8 & 홈플러스 가습기청정제 & 1 회 약 $10 \mathrm{ml}(2 \sim 3 \mathrm{~L}$ 기준 $)$ & 살균제 & PHMG P \\
\hline 9 & 앤 위드(파란색) & $\begin{array}{l}\text { 가습기에 물을 가득 채운 후 } \\
1 \text { 정 }\end{array}$ & $\begin{array}{l}\text { 이염화이소시아뉼산나트륨, } \\
\text { 오렌지향 }\end{array}$ & NI \\
\hline 10 & 이플러스 가습기살균제 & 약 $10 \mathrm{ml}(2 \sim 3 \mathrm{~L}$ 기준 $)$ & 미생물 성장 억제 성분 & CMIT/MIT \\
\hline 11 & 와이즐렉 가습기살균제 & 10 ml(2 3 L 기준) & 살균제 & PHMG P \\
\hline 12 & 맑은나라 & 1 회 약 $10 \mathrm{ml}(2 \sim 3 \mathrm{~L}$ 기준 $)$ & 살균제 & PHMG P/MIT \\
\hline 13 & 홈워쉬 & 약 $10 \mathrm{ml}(2 \sim 3 \mathrm{~L}$ 기준 $)$ & 살균제 & NI \\
\hline 14 & 홈키파 가습기 한번에 싹 & 약 $10 \mathrm{ml}(2 \sim 3 \mathrm{~L}$ 기준 $)$ & 살균제, 향 등 & NI \\
\hline 15 & 가습기 클린업 & $\begin{array}{l}\text { 약 } 20 \mathrm{ml}(2 \sim 3 \mathrm{~L} \text { 기준 }) / \\
\text { 약 } 10 \mathrm{ml}(2 \sim 3 \mathrm{~L} \text { 기준 })\end{array}$ & 히노끼정유, 히노끼티올 외 & PHMG H" \\
\hline 16 & 가습기퍼니셔 & 물 $2 \sim 3 \mathrm{~L}$ 당 $15 \sim 18 \mathrm{ml}$ & 미생물 성장 억제 성분 & CMIT/MIT \\
\hline 17 & 이마트 가습기살균제 & 약 $10 \mathrm{ml}(2 \sim 3 \mathrm{~L}$ 기준 $)$ & 미생물 성장 억제 성분 & CMIT/MIT \\
\hline 18 & 함박웃음 가습기세정제 & 1 회 약 $10 \mathrm{ml}(2 \sim 3 \mathrm{~L}$ 기준 $)$ & 살균제, 라벤다향 & CMIT/MIT \\
\hline 19 & 이코볼 살균필터 & 3 개월 & NI & NI \\
\hline 20 & 하이지어(필터용, 담채형) & NI & NI & NI \\
\hline 21 & 세퓨 가습기살균제 & 1 회 약 $10 \mathrm{ml}(2$ 3 L 기준 $)$ & PGH(원산지:덴마크),water & PHMG P, PGH \\
\hline 22 & 아토오가닉 & $\begin{array}{l}\text { 표면에 흐르지 않을 정도로 } \\
\text { 분사 }\end{array}$ & PGH & PHMG P, PGH \\
\hline 23 & 항알레르겐 & $\begin{array}{l}\text { 뚜껑에 2회 가습기 물통에 } \\
\text { 혼합 }\end{array}$ & 티트리오일 & NI \\
\hline 24 & 아토세이프 가습기 청정제 & 1회 $10 ~ 15 \mathrm{ml}(2 \sim 3 \mathrm{~L}$ 기준 $)$ & $\begin{array}{l}\text { 레몬라임추출성분/녹차추출 } \\
\text { 물/알로에추출물/허브추출물/ } \\
\text { 살균제 }\end{array}$ & /NI \\
\hline 25 & 아토세이프 가습기 항균제 & 1 회 $10 \sim 15 \mathrm{ml}(2 \sim 3 \mathrm{~L}$ 기준 $)$ & $\begin{array}{l}\text { 레몬라임추출성분/녹차추출 } \\
\text { 물/알로에추출물/허브추출물/ } \\
\text { 살균제 }\end{array}$ & /CMIT/MIT \\
\hline 26 & 앤 위드(흰색) & $\begin{array}{l}\text { 물통에 적정량 }(4 \sim 5 \mathrm{~L}) \text { 채운 후 } \\
1 \sim 2 \text { 정 }\end{array}$ & 살균제, 천연 오렌지향 & NI \\
\hline 27 & 모던라이프 가습기 살균볼 & 물 $1 \sim 1.5 \mathrm{~L}$ 당 1 개 & 케이씨라이트 & NI \\
\hline 28 & 세균닥터(정 제형) & 1정 & $\begin{array}{l}\text { 이염화이소시아뉼산나트륨/ } \\
\text { 아디핀산/탄산나트륨/탄산수 } \\
\text { 소나트륨 }\end{array}$ & NI \\
\hline 29 & 에어가드 리퀴드 & NI & $\begin{array}{l}\text { 타르펜, ABS오일, 아밀라제, } \\
\text { 은나노 등 } 18 \text { 가지 }\end{array}$ & NI \\
\hline 30 & 한국까르푸가습기세정제 & 15 18 ml(1컵)(2 3 L 기준) & 미생물 성장억제 성분 & NI \\
\hline 31 & 한방가습기보충액 & 1 회 약 $10 \mathrm{ml}(2 \sim 3 \mathrm{~L}$ 기준 $)$ & 한방원료(감로수), 나노은 & NI \\
\hline
\end{tabular}

${ }^{*}$ CMIT, Chloromethylisothiazolinone (CAS No. 26172-55-4); ${ }^{\dagger}$ MIT, Methylisothiazolinone (CAS No. 2682-20-4); " PHMG P, Polyhexamethylene guanidine phosphate (CAS No. 89697-78-9); ${ }^{\S}$ NI, no information; " PHMG H, Polyhexamethylene guanidine hydrochloride (CAS No. 57028-96-3); ${ }^{\uparrow}$ PGH, Oligo(2-)ethoxyethoxyethylguanidinechloride (CAS No. 374572-91-5). 
수 없었다. 하루 사용 횟수 등에 대한 제한이나 사 용자(영유아, 임산부, 노약자, 성인 등)에 따른 권고 량 구분은 없었다. 1 회 권장 사용량만 표기되어 있었다.

\section{3) 안전 보건 정보 및 사용상의 주의사항}

31 개의 제품 중 19 개가 용기 앞면에 '안전', '안심', ‘무해' 문구를 표기하였다(Table 3). 사용한 문구는 “ 인체 사용에 안전합니다", “인체에 무해합니다” 등 이다. '세퓨 가습기 살균제' 제품은 흡입 시에도 안 전하다고 표기되어 있었지만 영문은 “삼키다”의 뜻 인 'swallowed'로 표기되어 있었다. 폐 손상 등 건 강피해를 가장 많이 초래한 제품인 ‘옥시싹싹 뉴 가 습기 당번'은 “인체에 안전한 성분을 사용하여 안심 하고 사용할 수 있다", “살균 $99.9 \%$-아이에게도 안 심"이라고 표기했다.

사용상의 주의사항에는 피부 및 눈 노출, 경구 복 용(삼켰을 때) 사고 등에 대한 표기만 하고 호흡기 노출에 대한 건강위험을 표기한 제품은 없었다. 또 한 주의사항에 피부와 눈에 노출 시 응급 대처방안 은 있지만 경구 복용에 대한 내용은 작성되어 있지 않았다. 살균제 성분과 농도가 제품별로 다름에도 불 구하고 31 개 제품의 사용상 주의사항 등은 표기 내 용이 서로 비슷했다(Table 4).

\section{IV. 고 찰}

본 연구는 28 개 기업에서 판매한 31 개 제품 용기 에 표기된 안전보건정보를 정리하고 고찰했다. 이 연 구를 통해서 얻은 주요 쟁점을 정리했다.

첫째, 폐 손상 등 건강영향을 일으켰던 결정인자 인 살균제 화학물질 성분이나 위해성을 모든 제품이 정확히 표기하지 않았다. 2개 제품(세퓨 가습기 살 균제, 아토오가닉)은 oligo(2-(2-ethoxy) ethoxyethyl guanidine chloride (PGH, CAS No. 374572-91-5)로 성분은 표기하였지만, 해당 성분의 위해성 정도를 표 기하지 않았다. 오히려 인체에 안전하다고 표기했 다. 품질경영 및 공산품안전관리법(이하 품공법)에 따르면 세정제의 안전요건으로 품명, 종류, 모델명, 제조년월, 제조자명, 주소 및 전화번호, 제조국명, 성 분, 독성, 중량 또는 용량, 액성을 제품용기에 표기 하도록 하고 있다. ${ }^{3}$ 품공법에서 규정한 유해성분은 염산, 황산, 수산화나트륨, 수산화칼륨, 테트라클로로
에틸렌, 트리클로로에틸렌 함유 여부로 한정하였다. 가습기 살균제 주요 성분이었던 polyhexamethylene guanidine phosphate (PHMG 인산염, CAS No. 8969778-9), (PHMG 염산염), PGH, chloromethylisothiazolinone (CMIT, CAS No. 26172-55-4), methylisothiazolinone (MIT, CAS No. 2682-20-4)은 이 제한 조건에 해당 되지 않아 살균제의 안전관리가 이루어지지 않은 것 으로 판단한다. 제품 개발 당시 PHMG, PGH, CMIT/ MIT 등은 살균제 성분으로 잘 알려져 있었다.') 품 공법에서 세정제로 제한한 화학물질 성분은 극히 제 한적이다. 제품을 판매한 기업은 화학물질이 포함되 어 있음에도 독성학적 근거 없이 인체에 안전하고 무해한 성분을 사용한 것처럼 표기하였다.

둘째, 대기업(옥시 레킷벤키저, 롯데쇼핑, 삼성테스 코, 애경산업, 신세계이마트, 유공, 엘지화학 등)은 제품생산을 위탁하고 제품을 납품 받아 자체 브랜드 를 부착하여 판매했다(Table 1). 이들 기업들이 살균 제 성분의 농도, 물리·화학적 특성 등에 대한 정해 진 기준을 갖고 있었는지, 만약 기준이 있었다면 정 해진 기준을 관리하는 활동을 수행했는지 조사된 결 과는 없다. 가습기 살균제 제품인 경우 살균제 성분 과 농도 등은 건강 위험을 결정하기 때문에 철저히 관리하는 것이 기업의 당연한 의무 활동이다. 이는 원료인 PHMG 인산염 및 염산염, CMIT, MIT 성분 을 공급한 기업, 제품을 생산한 기업, 제품을 판매 한 기업 모두 해당된다. 모든 제품은 특성과 질을 결정하는 품질이 있고, 이를 관리하기 위한 활동(일 종의 품질관리 활동)을 한다. 지금까지 살균제 원료 생산, 가습기 살균제 제품 제조, 생산 기업이 살균제 의 물성, 농도 등을 관리(control)했는지 조사된 적이 없다. 대부분의 가습기 살균제 제품 제조 기업과 판 매기업은 위험의 핵심 원인인 살균제의 성분, 농도, 물성 등의 질(quality)을 검사하고 관리하는 활동을 하지 않았을 가능성이 높다. 가장 많은 폐 손상을 초래한 옥시싹싹 뉴 가습기 당번을 판매한 “옥시 레 킷벤키저"는 한빛화학에서 제품을 제조하게 했다.

박동욱 등이 연구한 가습기 살균제 제품 성분별 물리·화학적 특성과 농도 결과에서 제품 내, 제품 간, 판매시기별로 $\mathrm{PHMG}$ 인산염, $\mathrm{CMIT}, \mathrm{MIT}$ 농도 간의 유의미한 차이가 있었다. ${ }^{7}$ 이러한 결과는 제품 에서 살균제 성분 농도에 대한 관리가 엄격하게 이 루어지지 않았다는 것을 나타낸다. 판매기업은 제품 
Table 3. Safety and health information displayed on product container by humidifier disinfectant product

\begin{tabular}{|c|c|}
\hline 제품이름 & 안전관련 표기 문구 \\
\hline $\begin{array}{l}1 \text { 유공 가습기 } \\
\text { 메이트 }\end{array}$ & $\begin{array}{l}\text { - 가습기메이트는 가습기내에 서식하여 문제가 되는 세균과 곰팡이의 번식을 막고 물 } \\
\text { 때의 생성을 방지하는 가정용 미생물 번식 억제제로서 인체에는 전혀 해가 없습니다. } \\
\text { - 가족의 건강을 위해 가습기 물을 갈아줄 때 한번만 부어주십시오. }\end{array}$ \\
\hline 2 가습기당번 & - 인체에 안전한 성분을 사용하여 안심하고 사용할 수 있습니다. \\
\hline 3119 가습기살균제 & $\begin{array}{l}\text { • 인체에 안전한 성분으로 구성되어 안심하고 사용할 수 있습니다. } \\
\text { • 심리적 안정감에 도움이 되는 천연허브성분이 함유되어 있습니다. }\end{array}$ \\
\hline $\begin{array}{l}4 \text { 옥시싹싹 뉴 } \\
\text { 가습기 당번 }\end{array}$ & $\begin{array}{l}\text { - 인체에 안전한 성분을 사용하여 안심하고 사용할 수 있습니다. } \\
\text { - 살균 } 99.9 \% \text { 아이에게도 안심, 안정감을 주는 미량의 라벤더향 첨가 }\end{array}$ \\
\hline $\begin{array}{l}\text { 옥시싹싹 } \\
5 \text { 가습기당번 } \\
\text { (고체형) }\end{array}$ & $\begin{array}{l}\text { - 가습기 청소를 간편하게 살균 } 99.9 \% \text { 아이에게도 안심 } \\
\text { - 어떠한 종류의 부작용도 없으며 체내에 축적되지도 않습니다. } \\
\text { - 캡슐용기 및 부직포는 물속에서도 인체 무해합니다. } \\
\text { - 한번만 넣어주면 } 6 \text { 개월간 안심 }\end{array}$ \\
\hline $\begin{array}{l}6 \text { 주부사랑 } \\
\text { 가습기파트너 }\end{array}$ & $\begin{array}{l}\text { - 인체에 안전한 성분을 사용하여 안심하고 사용할 수 있습니다. } \\
\text { - 인체에 안전한 가습기 파트너 } \\
\text { - 국내 최초로 살균안전마크를 획득하여 더욱더 안심하고 사용하실 수 있습니다. } \\
\text { - 희석된 후에는 알레르기 피부에 전혀 이상이 없으니 안심하고 사용하십시오. }\end{array}$ \\
\hline $\begin{array}{l}7 \text { 홈플러스 } \\
\text { 가습기청정제 }\end{array}$ & - 인체에 안전한 성분을 사용하여 안심하고 사용할 수 있습니다. \\
\hline 8 앤위드( & $\begin{array}{l}\text { - 본 제품은 가습기내 세균과 실내공기 청정을 목적으로 개발된 제품으로 미국과 영국 } \\
\text { 의 공인기관에서 검증되었으며 세계 } 60 \text { 개국에서 사용되는 안전한 제품입니다. }\end{array}$ \\
\hline 9 홈워쉬 & $\begin{array}{l}\text { - 인체 안전 성분 사용으로 안심 가습하세요. } \\
\text { - 가습기내에 곰팡이, 물 때 세균의 발생을 근원적으로 막아줍니다. } \\
\text { - 가습기물 교체 시 한번 투여로 지속적인 효과를 발휘하며, 라벤다향이 상쾌한 기분과 } \\
\text { 살림욕 효과를 느끼게 합니다. }\end{array}$ \\
\hline $\begin{array}{l}10 \text { 함박웃음 } \\
\text { 가습기세정제 }\end{array}$ & $\begin{array}{l}\text { - 가습기내에 번식하는 세균과 물때의 발생을 근원적으로 막아줍니다. } \\
\text { - 가습기 물 교체시 한번 투여로 지속적 효과를 유지합니다. } \\
\text { • 라벤더향 첨가로 아로마테라피 효과를 보실 수 있습니다. } \\
\text { - 자율안전확인 }\end{array}$ \\
\hline 11 이코볼 & $\begin{array}{l}\text { - 인체에 무해하며 2차적인 오염이 없고 물을 활성화시켜 항상 쾌적한 가습이 가능합 } \\
\text { 니다. } \\
\text { - 살균력이 좋아 미용을 생각하는 여성, 아토피가 있는 어린이나 면역력이 약한 환자, 노 } \\
\text { 약자가 사용해도 위생적이고 안전합니다. }\end{array}$ \\
\hline $\begin{array}{l}12 \text { 하이지어 } \\
\text { (필터용, 담치 }\end{array}$ & $\begin{array}{l}\text { - No 화학제품, 석회질 제거/백화현상 제거 } \\
\text { - 실내공기정화, } 3 \text { 개월 안심사용 }\end{array}$ \\
\hline 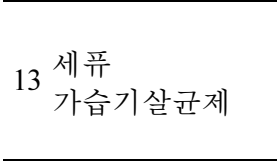 & $\begin{array}{l}\text { - 인체에 무해하며 흡입시에도 안전(OECD 423: not toxic if swallowed) } \\
\text { - 계면활성제 등 세척제 성분 및 유해성 분무첨가 } \\
\text { - 안심 살균 물질사용, 안전성 테스트완료 } \\
\text { - 이제 안심하고 가습기를 켜세요. }\end{array}$ \\
\hline 14 아 & $\begin{array}{l}\text { - } \mathrm{PGH} \text { 는 EU의 승인을 받고 유럽 환경국가에서 널리 쓰고 있는 안전한 살균 성분입니다. } \\
\text { - 인체에는 안전한 } \mathrm{PGH} \text { 가 소중한 우리가족을 감염으로부터 지켜드립니다. } \\
\text { - 교차감염예방, 가습기, 장난감, 유모차등 재질에 관계없이 어디나 안전하게 사용하실 수 } \\
\text { 있습니다. }\end{array}$ \\
\hline $\begin{array}{l}15 \text { 아토세이프 } \\
\text { 가습기 청정제 }\end{array}$ & 가 서부 \\
\hline $\begin{array}{l}16 \text { 아토세이프 } \\
\text { 가습기 항균제 }\end{array}$ & $\begin{array}{l}\text { - 인체에 안전한 성분을 사용하여 안심하고 사용할 수 있습니다. } \\
\text { - 가습기내에 번식하는 세균과 물때의 발생을 근원적으로 막아줍니다. } \\
\text { - 가습기 물 교체시 한번만 넣어주셔도 효과가 지속됩니다. } \\
\text { - 향균효과가 뛰어난 성분이 함유되어 세균이 번식하지 않도록 방지합니다. }\end{array}$ \\
\hline
\end{tabular}


Table 3. Continued

\begin{tabular}{|c|c|}
\hline No. 제품이름 & 안전관련 표기 문구 \\
\hline $\begin{array}{l}17 \text { 모던라이프 } \\
\text { 가습기 살균볼 }\end{array}$ & $\begin{array}{l}\text { - 우리집 가습기 안심 지킴이 } \\
\text { - 강력한 곰팡이, 세균 살균효과, 수질보호 및 향균기능, 최대 4개월 지속효과 }\end{array}$ \\
\hline $\begin{array}{l}18 \text { 세균닥터 } \\
\text { (정제형) }\end{array}$ & $\begin{array}{l}\text { - 세계적으로 } 100 \text { 여 개국 이상에서 사용하고 있으며, 강한 살균력과 안전성을 세계적으 } \\
\text { 로 인정받은 제품입니다. }\end{array}$ \\
\hline $\begin{array}{l}\text { 한국까르푸 } \\
\text { 가습기세정제 }\end{array}$ & ㄴㅈㅓ 성분 \\
\hline
\end{tabular}

생산을 위탁할 수 있지만 제품에 들어있는 건강위험 요인을 관리하고 책임져야 한다. 건강영향을 초래할 수 있는 화학물질의 농도 등 위험을 결정하는 요인 을 통제하고 관리하는 활동을 하지 않았다면 건강영 향에 대한 위험을 방기했다고 볼 수 있다.

셋째, 가습기 살균제 사용 시 주된 흡입 경로인 호 흡기 노출 위험에 대한 주의사항은 모든 제품에 표 기되어 있지 않았다. 가습기 살균제는 공기 중으로 분산되면 피부에도 흡수되는 것이 일반적이다. 가습 기 살균제의 주된 흡입 및 흡수경로는 호흡기와 피 부이다. 밀폐된 공간에서 장시간 사용 금지, 환기 등 호흡기 노출 가능성에 대한 표기가 없었다. 가습기 살균제의 주된 인체 흡입 경로가 호흡기임에도 불구 하고 이들 제품에는 호흡기 흡입에 따른 독성, 주의 및 권고사항, 비상조치 등에 대한 정보는 없었다.

넷째, 제품별 사용 권장량에 대한 독성학적 근거 를 찾을 수가 없었다(Table 2). 제품마다 들어간 살 균제 성분과 그 양이 다르지만 제품별로 사용 권장 부피(또는 양)는 대부분 비슷했다. 또한 사용 횟수제 한도 없었다. 가습기는 화학물질에 대한 방어력이 매 우 취약한 민감 계층부터 건강한 성인까지 남녀노소 모두 사용한다. 이론적으로 살균제 성분별 권장 사 용량은 사용 횟수와 함께 연령별로 모두 달라져야 한다. 또한 제품별로 제조하는 살충제 농도도 비슷 해야 한다는 가정이다. 사용자마다 민감도가 다르고 몸으로 흡수 또는 흡입되는 양은 하루 사용시간, 사 용기간, 사용량 등이 결정하기 때문에 단순히 권장 사용 부피로 건강피해를 예방할 수 없다. 제품에서 표기한 표준 권장 사용량(부피)은 안전한 양으로서 의미가 없다고 볼 수 있다.

다섯째, 가습기 살균제의 원료 공급, 제조 및 판매 기업에 대한 공정거래위원회 제재는 차이가 있었다. 이러한 차이는 제품별 폐 손상 등 건강피해와 안전

http://www.kseh.org/
보건정보에 대한 허위 광고 등을 근거로 볼 때 과 학적으로 이해할 수 없는 점들이 있다.

「표시·광고의 공정화에 관한 법률」(약칭: 표시광 고법), 제 3 조 제 1 항 제 1 호(거짓·과장의 표시·광고)에 의한 공정거래위원회 제재 조치에서 차이다. ${ }^{10)} 2012$ 년 공정거래위원회는 인체에 위해성이 확인된 $\mathrm{PHMG}$ 인산염, $\mathrm{PGH}$ 성분의 살균제를 판매하면서 제품 용 기에 안전하다고 허위 표기를 한 ‘옥시싹싹 뉴 가습 기 당번', ‘홈플러스 가습기 청정제', ‘세퓨 가습기 살균제', '아토오가닉 가습기 살균제'의 4 개 판매기 업에 대해 거짓·과장 광고에 대한 시정명령, 과징금 부과 등을 검찰에 고발한 바 있다. ${ }^{11-14)}$ 대법원(2014 년)은 "살균제 성분의 안전성이 검증되지 않았는데 도 인체에 안전한 성분을 사용했다고 표기하면 소비 자가 오인할 우려가 있다"며 이는 공정한 거래질서 를 해치는 거짓, 과장이기 때문에 시정조치 및 과징 금을 부과한 공정거래위원회의 처분이 정당하다고 판결하였다. 인체에 유해한 성분이 함유된 가습기 살균제를 안전한 것처럼 표기해 판매한 '과장광고' 혐의였다. 인체에 안전한 성분을 사용하였다는 표현 을 하지 않은(무표시) 롯데마트(와이즐렉 가습기 살 균제) 및 글로엔엠(가습기 클린업)에 대해서는 인체 위해성 여부를 은폐 누락한 기만 행위로 경고조치 했다. ${ }^{15)}$ 한편, 조사 당시 유해성이 확인되지 않았다 는 이유로 CMIT/MIT 성분의 가습기 살균제를 제 조 및 판매 기업인 애경산업, 이마트, 에스케이케미 칼에 대해서도 무혐의로 심의·종결했다. ${ }^{16,17)}$ 가습기 살균제 제품 허가 이전(1994년)에도 외국 문헌에서 CMIT/MIT는 피부 과민성 질환을 초래하는 것이 잘 알려져 있다. 이뿐만 아니라 천식 등 호흡기 질 환을 초래하는 것으로 보고된 바 있었다. ${ }^{18-20)}$ 심지어 동물실험에서는 뇌 독성이 있다는 연구결과도 보고 되었다. ${ }^{21)}$ 대부분의 제품 판매기업은 인체에 해로운

J Environ Health Sci 2017; 43(5): 349-359 
Table 4. Information related to safety and health by humidifier disinfectant brand

\begin{tabular}{|c|c|c|c|c|c|c|c|}
\hline 제품명 & 어린이주의* & 용도" & 사용방법: & 보관\& & 경구" & 눈" & 피부" \\
\hline 1 유공 가습기메이트 & $\mathrm{O}$ & $\mathrm{O}$ & $\mathrm{O}$ & $\mathrm{O}$ & $\mathrm{O}$ & $\mathrm{O}$ & $\mathrm{O}$ \\
\hline 2 가습기당번 & $\mathrm{O}$ & $\mathrm{O}$ & $\mathrm{X}$ & $X$ & $\mathrm{O}$ & $\mathrm{O}$ & $\mathrm{O}$ \\
\hline 3119 가습기살균제 & $\mathrm{O}$ & $\mathrm{X}$ & $\mathrm{X}$ & $\mathrm{O}$ & $\mathrm{O}$ & $\mathrm{X}$ & $\mathrm{X}$ \\
\hline 4 옥시싹싹 뉴 가습기 당번 & $\mathrm{O}$ & $\mathrm{O}$ & $\mathrm{X}$ & $\mathrm{X}$ & $\mathrm{O}$ & $\mathrm{O}$ & $\mathrm{O}$ \\
\hline 5 옥시싹싹 가습기당번(고체형) & $\mathrm{X}$ & $\mathrm{X}$ & $\mathrm{X}$ & $\mathrm{X}$ & $\mathrm{X}$ & $\mathrm{X}$ & $\mathrm{X}$ \\
\hline 6 애경 가습기메이트 & $\mathrm{O}$ & $\mathrm{X}$ & $\mathrm{O}$ & $\mathrm{O}$ & $\mathrm{O}$ & $\mathrm{O}$ & $\mathrm{O}$ \\
\hline 7 주부사랑 가습기파트너 & $\mathrm{O}$ & $\mathrm{O}$ & $\mathrm{O}$ & $X$ & $\mathrm{O}$ & $\mathrm{O}$ & $\mathrm{O}$ \\
\hline 8 홈플러스 가습기청정제 & $\mathrm{O}$ & $\mathrm{O}$ & $X$ & $\mathrm{X}$ & $\mathrm{O}$ & $\mathrm{O}$ & $\mathrm{O}$ \\
\hline 9 앤위드(파란색) & $\mathrm{O}$ & $\mathrm{X}$ & $\mathrm{X}$ & $\mathrm{X}$ & $\mathrm{O}$ & $X$ & $\mathrm{X}$ \\
\hline 10 이플러스 가습기살균제 & $\mathrm{O}$ & $\mathrm{X}$ & $\mathrm{O}$ & $\mathrm{O}$ & $\mathrm{O}$ & $\mathrm{O}$ & $\mathrm{O}$ \\
\hline 11 와이즐렉 가습기살균제 & $\mathrm{O}$ & $\mathrm{O}$ & $\mathrm{X}$ & $\mathrm{O}$ & $\mathrm{O}$ & $\mathrm{O}$ & $\mathrm{O}$ \\
\hline 12 맑은나라 & $\mathrm{O}$ & $\mathrm{O}$ & $\mathrm{O}$ & $X$ & $\mathrm{O}$ & $\mathrm{O}$ & $\mathrm{O}$ \\
\hline 13 홈워쉬 & $\mathrm{O}$ & $\mathrm{O}$ & $\mathrm{O}$ & $\mathrm{O}$ & $\mathrm{O}$ & $\mathrm{O}$ & $\mathrm{O}$ \\
\hline 14 홈키파 가습기 한번에 싹 & $\mathrm{O}$ & $\mathrm{O}$ & $\mathrm{O}$ & $\mathrm{O}$ & $\mathrm{O}$ & $\mathrm{O}$ & $\mathrm{O}$ \\
\hline 15 가습기클린업 & $\mathrm{O}$ & $\mathrm{O}$ & $\mathrm{O}$ & $\mathrm{X}$ & $\mathrm{O}$ & $\mathrm{O}$ & $\mathrm{O}$ \\
\hline 16 가습기퍼니셔 & $\mathrm{O}$ & $\mathrm{O}$ & $\mathrm{X}$ & $\mathrm{O}$ & $\mathrm{O}$ & $\mathrm{O}$ & $\mathrm{O}$ \\
\hline 17 이마트 가습기살균제 & $\mathrm{O}$ & $\mathrm{X}$ & $\mathrm{O}$ & $\mathrm{O}$ & $\mathrm{O}$ & $\mathrm{O}$ & $\mathrm{O}$ \\
\hline 18 함박웃음 가습기세정제 & $\mathrm{O}$ & $\mathrm{O}$ & $\mathrm{O}$ & $\mathrm{O}$ & $\mathrm{O}$ & $\mathrm{O}$ & $\mathrm{O}$ \\
\hline 19 이코볼 살균필터 & $\mathrm{X}$ & $\mathrm{X}$ & $\mathrm{X}$ & $\mathrm{X}$ & $\mathrm{X}$ & $X$ & $X$ \\
\hline 20 하이지어(필터용, 담채형) & $\mathrm{X}$ & $\mathrm{X}$ & $\mathrm{X}$ & $\mathrm{X}$ & $\mathrm{X}$ & $\mathrm{X}$ & $X$ \\
\hline 21 세퓨 가습기살균제 & $\mathrm{O}$ & $\mathrm{X}$ & $\mathrm{O}$ & $\mathrm{X}$ & $\mathrm{X}$ & $\mathrm{X}$ & $X$ \\
\hline 22 아토오가닉 & $\mathrm{O}$ & $\mathrm{X}$ & $\mathrm{X}$ & $\mathrm{X}$ & $\mathrm{O}$ & $\mathrm{X}$ & $\mathrm{X}$ \\
\hline 23 항알레르겐 & $\mathrm{O}$ & $\mathrm{X}$ & $\mathrm{X}$ & $\mathrm{X}$ & $\mathrm{O}$ & $\mathrm{O}$ & $X$ \\
\hline 24 아토세이프 가습기 청정제 & $\mathrm{X}$ & $\mathrm{X}$ & $\mathrm{X}$ & $X$ & $\mathrm{X}$ & $\mathrm{X}$ & $X$ \\
\hline 25 아토세이프 가습기 항균제 & $\mathrm{O}$ & $\mathrm{O}$ & $\mathrm{X}$ & $\mathrm{O}$ & $\mathrm{O}$ & $\mathrm{O}$ & $X$ \\
\hline 26 앤위드(흰색) & $\mathrm{O}$ & $\mathrm{O}$ & $\mathrm{X}$ & $\mathrm{X}$ & $\mathrm{O}$ & $\mathrm{X}$ & $\mathrm{X}$ \\
\hline 27 모던라이프 가습기 살균볼 & $\mathrm{X}$ & $\mathrm{X}$ & $\mathrm{X}$ & $\mathrm{X}$ & $\mathrm{X}$ & $\mathrm{X}$ & $\mathrm{X}$ \\
\hline 28 세균닥터(정제형) & $\mathrm{X}$ & $\mathrm{X}$ & $\mathrm{X}$ & $X$ & $\mathrm{O}$ & $\mathrm{X}$ & $X$ \\
\hline 29 에어가드 리퀴드 & $\mathrm{O}$ & $\mathrm{O}$ & $\mathrm{X}$ & $\mathrm{O}$ & $\mathrm{X}$ & $\mathrm{O}$ & $\mathrm{X}$ \\
\hline 30 한국까르푸가습기세정제 & $\mathrm{O}$ & $\mathrm{O}$ & $\mathrm{O}$ & $\mathrm{O}$ & $\mathrm{O}$ & $\mathrm{O}$ & $\mathrm{O}$ \\
\hline 31 한방가습기보충액 & $\mathrm{X}$ & $\mathrm{X}$ & $\mathrm{X}$ & $\mathrm{X}$ & $X$ & $\mathrm{X}$ & $X$ \\
\hline
\end{tabular}

"어린이의 손에 닿지 않는 곳에 두십시오; ${ }^{\dagger}$ 용도 이외에는 사용하지 마십시오; ${ }^{*}$ 정해진 사용방법을 지키십시 오; § 직사광선을 피하여 실온에 보관 하십시오; " 마시거나 피부에 닿거나 눈에 들어간 경우에는 흐르는 물로 잘 씻어 낸 후 의사와 상의하십시오. 피부가 민감하신 경우에는 사용 시 고무장갑을 사용하십시오.

화학성분이 포함되어 있음에도 불구하고 인체에 안 전한 성분을 사용한 것처럼 '안전' 또는 '안심' 문 구를 표기하였다(Table 4). 건강상의 안전을 입증할 만한 과학적 근거도 찾을 수 없었다. 이뿐만 아니라 PHMG 인산염 및 염산염, PGH, CMIT, MIT 외 다 른 화학물질의 살균제 성분들이 들어 있는 가습기
살균제 제품( 15 개, Table 3 )도 대부분 안전한 것처 럼 용기에 과장 광고를 했음에도(Table $2,3,4$ ), 이 들에 대한 공정거래위원회의 제재는 차이가 있었다. 3차 폐 손상 조사까지 CMIT/MIT 성분이 들어 있 는 살균제 제품만을 사용한 피해신고자 중 확실한 폐 손상자가 다수 발견되었다. 1차 “가습기 살균제 
피해자 조사(2013 2014년)"에서 가습기 살균제 관 련 가능성이 있는(possible) 피해자가 4명이 발견되 었고, 2차 조사에서도 확실한 연관(definite) 2 명, 상 당한 연관(probable) 1명, 가능성이 있는 연관 피해 자가 1명 발생하였다. 3차 조사(2015 2017년)에서 도 상당한 연관 폐 손상자가 5 명, 가능성이 있는 피 해자는 11 명으로 판정되었다. 이 결과는 CMIT/MIT 가 들어있는 가습기 살균제 제품만을 쓴 피해 신고 자 총 106명(1차 23명, 2차 13명, 3차 70명)에 대한 판정결과에서 확인된 것이다. 폐 손상자 24 명 중 20 명이 애경 가습기메이트 제품만을 썼고 2 명은 이 제 품을 $60 \%$ (이마트 가습기살균제 $40 \%$ ) 사용하였다고 응답했다. ${ }^{2)}$ 특히 CMIT/MIT가 들어있는 제품만을 사용한 다수의 폐 손상자가 발견되었음에도 불구하 고 아직까지 검찰 고발도 없었고, 과장 광고 등에 대한 시정명령, 과태료, 과징금 조차도 부과된 적이 없다. 제품별 폐 손상 등 피해 상황, 살균제 성분의 문헌상 건강위험, 안전보건정보 표기 등을 근거로 일 관성 있는 검찰 수사 및 공정거래위원회 제재조치가 이루어져야 한다.

마지막으로, 사망, 폐 손상, 천식 등 건강피해 참 사를 일으킨 직접적 원인인 가습기 살균제 제품의 건강위험을 평가하기 위한 기본정보가 매우 부족하 다. 제품을 판매할 때 홍보했던 안전보건정보를 정 리하고 분석한 것도 본 연구가 처음이다. 가습기 살 균제가 판매되기 시작한 지(1994년) 20년이 넘었고, 건강피해가 본격적으로 알려지기 시작한 지(2011년) 6년이 지났는데도 불구하고 정부는 건강피해의 직접 적 원인인 제품에 대한 기본적인 정보(제품 수, 성 분, 농도 등 물성 특성 및 판매량 등)를 공식적으로 조사한 적이 없다. 지금까지 가습기 살균제 제품과 관련된 연구 또는 조사는 2건에 불과하다. 2011년 가습기살균제 피해가 알려진 직후 보건복지부가 2011 년 국정감사에서 가습기 10 개 살균제 제품 중 $\mathrm{PHMG}$ 인산염 및 염산염, $\mathrm{PGH}, \mathrm{CMIT} / \mathrm{MIT}$ 등 살균제 농 도를 보고했다. ${ }^{22)}$ 이 중 $\mathrm{PHMG}$ 인산염이 들어 있는 제품은 3 개(옥시싹싹 뉴 가습기 당번, 와이즐렉 가 습기살균제, 홈플러스 가습기청정제), $\mathrm{PHMG}$ 염산염 이 들어 있는 제품은 1 개(가습기 클린업), $\mathrm{PGH}$ 가 들 어 있는 제품은 2개(세퓨 가습기살균제, 아토오가닉 가습기살균제) 그리고 CMIT와 MIT 혼합물이 들어 있는 제품은 4 개(애경 가습기메이트, 이마트 가습기
살균제, 함박웃음 가습기세정제, 산도깨비 가습기퍼 니셔)였다. 본 연구는 1994년부터 판매된 가습기 살 균제 제품 수를 총 37 개로 파악했다. 모두 가습기에 살균 목적으로 화학물질(살균제)을 넣어서 사용한 제 품들이다. 이 중 6 개는 제품에 대한 안전정보를 구 할 수 없었지만 본 연구결과와 비슷할 것으로 판단한다.

최근(2017)에 국립환경과학원이 가습기 살균제 제 품의 성분별 물리·화학적 특성과 농도를 조사한 바 있다. ${ }^{7)}$ 50개 시료에서 PHMG, PGH, CMIT/MIT의 농도와 물성 등을 조사했다. 이 연구에서 그 동안 살균제 성분이 알려지지 않았던 제품인 '맑은나라 가습기 살균제'는 $\mathrm{PHMG}$ 와 MIT 성분이 함유되어 있었으며, ‘아토세이프 가습기 항균제'에서는 CMIT 와 MIT 성분이 함께 들어 있는 것을 확인했다. ${ }^{7)}$ 유 통된 제품에 들어 있는 살균제 성분조차도 완벽하게 조사되지 않았다. 2011년 제품 판매가 중지된 지 6 년이 지나서 조사에 어려움이 있겠지만 더 늦기 전 에 제품의 위험과 관련된 모든 정보를 조사해야 한 다. 화학물질인 살균제에 의한 만성적인 건강영향은 앞으로 계속될 것이다. 건강영향의 직접적 원인인 제 품 정보는 향후 피해질환 특성, 경향, 연관 등을 파 악하고 이해하는데 중요하게 활용될 것으로 판단한 다. 이는 무엇보다 가습기 살균제 원료 공급, 제조, 판매 기업의 위험관리 책임을 규명하고 이들을 처벌 하는데 중요하게 활용될 수 있다. 생활화학제품의 복 잡한 위험 정보를 사용자가 모두 인식하는 것은 어 렵다. 이에 소비자 권리를 제품에 명확하게 표시할 것을 제안한다. 예를 들면 “이 제품을 사용할 때 나 타난 사고, 건강 피해 등을 입었을 경우 00000 로 신 고하십시오"를 용기 전면에 표기하게 하는 것도 방 법이다. 이를 위해서는 제품 사고 사례를 법적으로 수집할 수 있는 국가 조직이 필요할 것으로 판단된 다. 미국 등 경제협력개발기구(OECD) 가입 국가가 모두 운영하고 있는 물질중독센터(poison center)가 이 기능을 담당하고 있다. ${ }^{23)}$

\section{V. 결 론}

지금까지 판매된 31 개 가습기 살균제 제품에 표기 된 안전보건정보를 건강영향 측면에서 분석했다. 6 개 제품을 제외한 모든 제품 용기에는 살균제 성분 이 표기되지 않았으며, 독성학적 근거 없이 사용방 
법과 '안전', ‘안심', ‘무해' 문구를 표기했다. 모든 제품이 안전보건에 대한 과장 또는 허위 정보를 표 기했다. 주된 인체 흡입 및 흡수 경로인 호흡기와 피부 노출에 따른 주의사항 정보는 없었다. 가습기 살균제 원료 제조, 제품 생산과 판매, 제품 사용 과 정에서 살균제 성분에 대한 기업의 위험 관리는 없 었다. 건강피해가 나타난 후 정부는 가습기 살균제 참사의 직접적 원인인 제품에 대한 정보(제품 수, 살 균제 성분과 농도, 제품의 질 관리)를 정확하게 조 사한 적이 없다. 검찰 수사와 공정거래위원회 제재 도 일부 제품에 대해서만 이루어져 일관성이 없고 미흡하다. 특히 24 명의 폐 손상 피해자가 발생하고 문헌에서도 건강위험이 명백하게 보고된 CMIT/MIT 를 함유한 제품을 제조하고 판매한 기업에 대한 처 벌은 이루어지지 않았다. 가습기 살균제 제품의 위 험과 관련한 정보들은 향 후 피해질환 특성, 경향, 연관 등을 파악하고 살균제 원료 제조, 생산, 판매 기업의 위험관리 책임을 규명하는데 중요하게 활용 될 수 있다.

\section{References}

1. Park DU, Ryu SH, Roh HS. Distribution of health problems associated with humidifier disinfectant by year. J Environ Health Sci. 2016; 42(6): 365-374.

2. Park et al. Lung injury caused by a mixture of chloromethylisothiazolinone (CMIT) and methylisothiazolinone (MIT) used as disinfectant in humidifier, 2017 [submitted].

3. Korea Center for Disease Control and Prevention (KCDC). 1st Study on the relationship between the use of humidifier disinfectant and lung injury; 2014.

4. Yonhap News. Unauthorized humidifier disinfectants still brazenly sold. Available: http://www.yonhapnews.co.kr/bulletin/2016/07/28/0200000000 AKR20160728082000004.HTML [accessed 12 October 2017].

5. The medical news. Avoid unauthorized qusi-drug "Eekoball disinfection filter". Available: http://www. bosa.co.kr/news/articleView.html?idxno $=607571$ [accessed 12 October 2017].

6. Choi H, Kim JJ, Lee DG. Antifungal activity of the cationic antimicrobial polymer-polyhexamethylene guanidine hydrochloride and its mode of action. Fungal Biol. 2017; 121(1): 53-60.

7. Park DU, Kwon JH, Oh HB. Physicochemical char- acteristics by humidifier disinfectant brands, National Institute of Environmental Health, 2017.

8. Yonhap News. Manslaughter case for eight humidifier disinfectant manufactures forwarded to Public Prosecution's Office. Available: http://www.yonhapnews.co.kr/bulletin/2015/09/18/ 0200000000AKR20150918204900004.HTML?input $=1195 \mathrm{~m}$ [accessed 12 October 2017].

9. Korean Broadcasting System (KBS). Humidifier disinfectants sold despite awareness of endangerment... company to blame. Available: http:// news.kbs.co.kr/news/view.do?ncd=3150426\&ref $=$ A [accessed 12 October 2017].

10. Fair Trade Commission. Fair Trade Commission Review: Act on Fair Labeling and Advertising. 2014.

11. Fair Trade Commission. Case on Unlawful labeling of Oxy Reckitt Benckiser Co., Ltd. Decision number: 2012-200. 2012.

12. Fair Trade Commission. Case on Unlawful labeling of Home plus Co., Ltd. Decision number: 2012201. 2012.

13. Fair Trade Commission. Case on Unlawful labeling of Butterfly Effect Co. Ltd. Decision number: 2012202. 2012.

14. Fair Trade Commission. Case on Unlawful labeling of Atorganic Co. Ltd. Decision number: 2012-203. 2012.

15. Fair Trade Commission. Sanctions Imposed on Humidifier Disinfectant Seller for False Labeling on Safeness. 2012.

16. Fair Trade Commission. Case on unlawful labeling and advertising of E-MART Co., Ltd. and Aekyung Industrial Co., Ltd. Decision number: 2016-282. 2016.

17. Fair Trade Commission. Case on unlawful labeling and advertising of Aekyung Industrial Co., Ltd. And SK chemicals Co., Ltd. Decision number: 2016-285. 2016.

18. Lundov MD, Zachariae C, Menné T, Johansen JD. Airborne exposure to preservative methylisothiazolinone causes severe allergic reactions. BMJ. 2012; 345: e8221.

19. Scientific Committee on Consumer Safety (SCCS). OPINION ON the mixture of 5-chloro-2-methylisothiazolin-3(2H)-one and 2-methylisothiazolin-3(2H)one; 2009.

20. Lundov MD, Mosbech H, Thyssen JP, Menné T, Zachariae C. Two cases of airborne allergic contact dermatitis caused by methylisothiazolinone in paint. Contact Dermatitis. 2011; 65(3): 176-178. 
21. He K, Huang J, Lagenaur CF, Aizenman E. Methylisothiazolinone, a neurotoxic biocide, disrupts the association of SRC family tyrosine kinases with focal adhesion kinase in developing cortical neurons. J Pharmacol Exp Ther. 2006; 317(3): 1320-1329.

22. Korea Center for Disease Control and Prevention (KCDC). Analytical results of the chemical components of various humidifier disinfectant brands from
KCDC's parliamentary inspection. Document number: Department of epidemiology research-822. 2011.

23. Mowry JB, Spyker DA, Cantilena JR LR, McMillan N, Ford M. 2013 annual report of the American association of poison control centers' National poison data system (NPDS): 31st annual report. Clin Toxicol. 2014; 52(10): 1032-1283. 